\title{
Identification, Isolation and Characterization of Unknown Acid Degradation Product of Nevirapine
}

\author{
Vasudev Pottabathini1, Vijayacharan Gugulothu', Muralidharan Kaliyaperumal2, \\ Satyanarayana Battu ${ }^{1 *}$ \\ ${ }^{1}$ Department of Chemistry, University College of Science, Osmania University, Hyderabad, India \\ ${ }^{2}$ GVK Bio Sciences Pvt. Ltd., Hyderabad, India \\ Email: *satyambchem@yahoo.co.in, vasudev_netha@yahoo.com
}

How to cite this paper: Pottabathini, V., Gugulothu, V., Kaliyaperumal, M. and Battu, S. (2016) Identification, Isolation and Characterization of Unknown Acid Degradation Product of Nevirapine. American Journal of Analytical Chemistry, 7, 663-678. http://dx.doi.org/10.4236/ajac.2016.79061

Received: August 1, 2016

Accepted: September 25, 2016

Published: September 28, 2016

Copyright $\odot 2016$ by authors and Scientific Research Publishing Inc. This work is licensed under the Creative Commons Attribution International License (CC BY 4.0).

http://creativecommons.org/licenses/by/4.0/

\begin{abstract}
A Novel stability indicating RP-UPLC chromatographic method was developed for analysis of Nevirapine in pharmaceutical formulations. The developed RP-UPLC method is superior in technology to conventional RP-HPLC with respect to speed, resolution, solvent consumption and cost of analysis. Nevirapine was subjected to the stress conditions like acid, base, thermal, oxidative and photolytic degradation. $\mathrm{Ne}-$ virapine was found to degrade significantly in acid and thermal degradation. In acid degradation relative retention time with 0.42 is found as unknown impurity. New impurity was identified, isolated using mass based auto purification system and characterized by ${ }^{1} \mathrm{H}$ NMR $\left({ }^{1} \mathrm{D}\right.$ and $\left.{ }^{2} \mathrm{D}\right)$ and HRMS experiments. Isolated impurity was showing molecular weight of 244.10 , molecular formula $\mathrm{C}_{12} \mathrm{H}_{12} \mathrm{~N}_{4} \mathrm{O}_{2}$ and its name as 2-(3-Amino-4-methylpyridin-2-ylamino)nicotinic acid. The calibration graph was linear and the method showed less deviation in accuracy results. The test solution was found to be stable for 20 days when stored in the refrigerator between $2^{\circ} \mathrm{C}$ to $8^{\circ} \mathrm{C}$. The developed RP-UPLC method was validated and meets the requirements delineated by the International Conference on Harmonization ( $\mathrm{ICH}$ ) guidelines. The intra-day and inter-day variation was less than $1 \%$. The method was reproducible and selective for the estimation of Nevirapine. Because the method could effectively separate the drug from its degradation products, it can be employed as a stability-indicating method.
\end{abstract}

\section{Keywords}

Nevirapine, Method Development, Validation, Forced Degradation, Unknown Impurity, Isolation, Characterization, NMR, HRMS

\section{Introduction}

Nevirapine is structurally a member of the dipyridodiazepinone chemical class of 
compounds. The chemical name of nevirapine is 11-cyclopropyl-4-methyl-5H-dipyrido [3, 2-b:2', 3'-e][1,4] diazepin-6 (11H)-one. Nevirapine is an anti-HIV drug that reduces the amount of virus in the body. Anti-HIV drugs such as Nevirapine slow down damage to the immune system and prevent the occurrence of AIDS-defining illnesses. Nevirapine belongs to a class of drugs known as non-nucleoside reverse transcriptase inhibitors (NNRTIs). The enzyme reverse transcriptase converts single-stranded viral RNA into DNA. Drugs in the NNRTI class stop HIV from replicating within cells by binding near reverse transcriptase's active site and inhibiting polymerase activity. $\mathrm{Ne}$ virapine is able to reduce HIV-1 viral load and increase CD4 cell counts in the majority of people when taken in combination with at least two other antiretroviral drugs. Nevirapine is not active against HIV-2 [1].

Nevirapine was licensed after three clinical trials found that the combination of $\mathrm{Ne}$ virapine, AZT (zidovudine, Retrovir) and ddI (didanosine, Videx) brought about greater decreases in viral load and increases in CD4 cell counts than AZT and ddI taken without Nevirapine in patients who had not taken antiretroviral therapy before. The triple combination also led to fewer cases of HIV disease progression [2] [3].

Several studies have reported that triple regimens including Nevirapine are as effective as protease inhibitor-containing regimens [4]. Concerns about the potency of $\mathrm{Ne}-$ virapine in people who begin treatment with high viral load have been dispelled by these studies. A recent study has also demonstrated that Nevirapine is a safe and effective option for patients beginning therapy with a CD4 cell count below $200 \mathrm{cells} / \mathrm{mm}^{3}$. Treatment with Nevirapine mono-therapy is notorious for rapidly eliciting resistance due to mutations of the amino acids surrounding the NNRTI binding site [5]-[8].

Few analytical methods are available in the literature for the determination of Nevirapine and other antiviral drugs in plasma. Few LC-MS methods are also available in literature to quantify the Nevirapine along with other retroviral drugs [9]-[15]. However, nowhere in the literature described shortest stability indicating UPLC method for analysis of Nevirapine.

It is important to study the all possible forced degradation pathways and degradation products for the drug Nevirapine, as new formulations and new manufacturing processes are developing day to date. Hence performed all degradation studies for the drug and thorough literature survey indicated that there is no data available on the characterization of acid degradation product of Nevirapine in literature. The present research work describes the stability indicating UPLC analysis of Nevirapine, identification, isolation and characterization of unknown degradation product formed in the acid degradation study. Developed method can be used to quantify the drug in formulations and in bulk drugs. Chemical structures of Nevirapine and related impurities were shown in Figure 1.

\section{Experimental}

\subsection{Materials}

NEVIVIR tablets containing Nevirapine with labeled amount of $200 \mathrm{mg}$ per tablet 


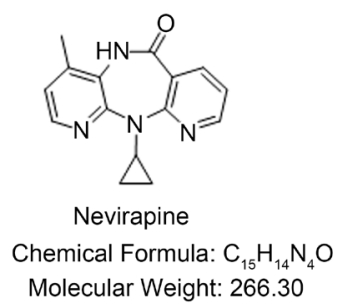

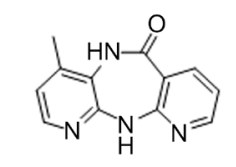

Related Compound-A Chemical Formula: $\mathrm{C}_{12} \mathrm{H}_{10} \mathrm{~N}_{4} \mathrm{O}$ Molecular Weight: 226.23

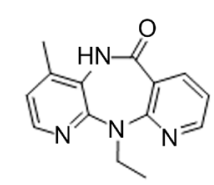

Related Compound-B Chemical Formula: $\mathrm{C}_{14} \mathrm{H}_{14} \mathrm{~N}_{4} \mathrm{O}$ Molecular Weight: 254.29
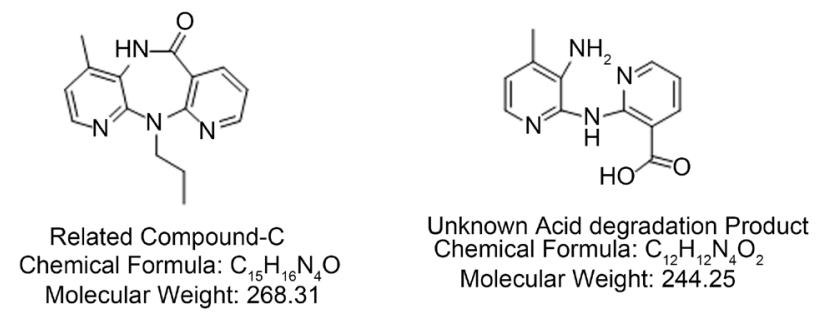

Figure 1. Nevirapine and its related impurities.

manufactured by Hetero drugs are procured from local pharmacy. Solvents and buffers used for analysis were HPLC grade acetonitrile from Merck, ammonium bicarbonate from sigma aldrich. High purity water was obtained from Millipore Milli-Q Plus water purification system.

\subsection{Equipment}

\subsubsection{Ultra Performance Liquid Chromatography}

The Liquid chromatography system used for the method development and method validation consists of quaternary gradient pumps with auto sampler and auto injector connected with photo diode array detector controlled with Empower software. Eclipse plus C18 $(50 \times 4.61 .8 \mu)$ column was used from Agilent.

\subsubsection{UPLC Chromatographic Conditions for Analysis of Nevirapine}

Based on all the method development trials the below chromatographic conditions were finalized for analysis of Nevirapine, separation of degradation products from drug and for method validation. Optimized chromatographic conditions were shown in $\mathrm{Ta}$ ble 1 .

\subsubsection{Mass Mediated Auto Purification Preparative HPLC}

Waters Mass mediated purification system was used to purify the degradation products. Mass mediated preparative HPLC equipped with waters pump module 2545, UV detector module 2996, mass detector module 3100, sample manager module 2767 and Mass lynx data handling system was used. $0.1 \%$ Formic acid was used as makeup solution for purification. Finalized preparative chromatographic conditions were shown in below Table 2 .

\subsubsection{HRMS (High Resolution Mass Spectrometry)}

Degradation products of Nevirapine were analyzed on the waters micro mass Q-TOF equipped with electrospray ionization ion source and degradation samples analyzed in 
positive mode. Caffeine $(\mathrm{m} / \mathrm{z}: 194.080383 \mathrm{Da})$ was used as internal standard to calibrate the mass range and mass accuracy. Data was acquired in positive mode using Mass lynx software.

\subsubsection{Nuclear Magnetic Resonance Spectroscopy ( $\left.{ }^{1} \mathrm{H},{ }^{13} \mathrm{C}-\mathrm{NMR}, \mathrm{HMBC}, \mathrm{HSQC}\right)$}

The ${ }^{1} \mathrm{H}$ and ${ }^{13} \mathrm{C}$ NMR spectral data of all degradation products were recorded in DMSO- $\mathrm{d}_{6}$ at $400 \mathrm{MHz}$ on Bruker $400 \mathrm{MHz}$ advance NMR spectrometer. The ${ }^{1} \mathrm{H}$ and ${ }^{13} \mathrm{C}$ chemical shifts were reported on $\delta$ scale in ppm, relative to TMS ( $\delta 0.00 \mathrm{ppm})$ and

Table 1. Optimized chromatographic conditions of the method.

\begin{tabular}{cc}
\hline & Analytical chromatographic conditions \\
\hline Column & Eclipse Plus C18 $(50 \times 4.61 .8 \mu)$ \\
Mobile phase & Acetonitrile (B), $10 \mathrm{mM}$ Ammonium bicarbonate (A) \\
Program & Gradient \\
Flow rate & $0.6 \mathrm{~mL} / \mathrm{min}$ \\
Wavelength & $280 \mathrm{~nm}$ \\
Column Temperature & $35^{\circ} \mathrm{C}$ \\
Injection volume & $2 \mu \mathrm{L}$ \\
Diluent & Mobile phase $(50: 50)$ \\
Gradient program & $0 / 3,0.3 / 3,3.2 / 98,4 / 98,4.1 / 3$ \\
(Time/\%B) & \\
\hline
\end{tabular}

Table 2. Mass mediated preparative chromatographic conditions.

\begin{tabular}{|c|c|}
\hline \multicolumn{2}{|c|}{ Preparative Chromatographic Conditions } \\
\hline Column & X-Select HSS CN OBD ${ }^{\mathrm{TM}}(250 \times 195 \mu)$ \\
\hline Mobile phase & Acetonitrile (B), $10 \mathrm{mM}$ Ammonium bicarbonate (A) \\
\hline Programme & Gradient \\
\hline Flow rate & $20 \mathrm{~mL} / \mathrm{min}$ \\
\hline Wavelength & 280 \\
\hline Column temperature & Ambient \\
\hline Injection volume & $500 \mu \mathrm{L}$ \\
\hline Diluent & Mobilephase \\
\hline Gradient programme & (Time/\%B): $0 / 5,4 / 5,10 / 50,10.1 / 98,12 / 98,12.1 / 5,14 / 5$ \\
\hline \multicolumn{2}{|r|}{ Source voltages } \\
\hline Capillary $(\mathrm{kV})$ & 3.5 \\
\hline Cone $(\mathrm{V})$ & 35 \\
\hline \multicolumn{2}{|r|}{ Source Temperatures } \\
\hline Disolvation Temperature $\left({ }^{\circ} \mathrm{C}\right)$ & 350 \\
\hline \multicolumn{2}{|r|}{ Source Gas flow } \\
\hline Desolvation Gas flow (L/Hr) & 650 \\
\hline Cone $(\mathrm{L} / \mathrm{Hr})$ & 50 \\
\hline \multicolumn{2}{|r|}{ Analyser } \\
\hline LM Resolution & 15 \\
\hline HM Resolution & 15 \\
\hline Ion Energy & 0.5 \\
\hline Mass range & $150-850$ \\
\hline
\end{tabular}


DMSO-d ${ }_{6}(\delta 39.50 \mathrm{ppm})$ as internal standards respectively. HSQC and HMBC correlations were recorded for the same sample to get the further confirmation of compound.

\subsubsection{FT-IR}

The IR spectra was recorded in the solid state as $\mathrm{KBr}$ dispersion medium using Shimadzu IR Affinity-1 FT IR spectrophotometer.

\subsection{Sample Preparation}

\subsubsection{Preparation of Standard Solution}

Bulk Standard of Nevirapine was prepared by dissolving $10 \mathrm{mg}$ in $100 \mathrm{~mL}$ standard volumetric flask containing approximately $50 \mathrm{~mL}$ of diluent and the solution was sonicated for $30 \mathrm{~min}$, and the volume was made up to the mark with diluent to obtain a concentration of $100 \mu \mathrm{g} \cdot \mathrm{mL}^{-1}$. From this stock solution, working standard solutions were prepared for calibration by adding defined volumes of the stock standard solutions and mobile phase. The concentrations of Nevirapine in linearity solutions were $5.0,10.0,15.0,20.0,25.0 \mu \mathrm{g} \cdot \mathrm{mL}^{-1}$ respectively.

\subsubsection{Preparation of Sample Solutions}

Ten tablets were weighed to determine the average tablet weight and powdered in a mortar. Powder equivalent to $200 \mathrm{mg}$ of Nevirapine was transferred into a $200 \mathrm{~mL}$ volumetric flask. Sample solution kept on a rotary shaker for $30 \mathrm{~min}$ to disperse the material completely, followed by sonication for $30 \mathrm{~min}$, cooled to room temperature and mixed well. The sample solution was filtered through a $0.45 \mu \mathrm{m}$ Nylon-66 membrane syringe filter, and $1.5 \mathrm{~mL}$ of this solution was taken in a $100 \mathrm{~mL}$ volumetric flask and made up to volume with diluents to the concentration $15 \mu \mathrm{g} \cdot \mathrm{mL}^{-1}$.

\subsubsection{Generation of Stress Samples}

Specificity is the ability of the method to measure the analyte response in the presence of its potential impurities. As per ICH stability guidelines, different kinds of stress conditions i. e. heat, acidic, basic, oxidation and photolytic were employed [16] [17]. The details of the stress conditions applied were shown in Table 3.

\subsubsection{Preparation of Degradation Samples for Purification}

Degradation was observed in thermal and acidic conditions. Directly $200 \mathrm{mg}$ of Nevirapine kept in micro oven at $110^{\circ} \mathrm{C}$ for $24 \mathrm{~h}$ and degraded sample was dissolved in

Table 3. Stress study final conditions.

\begin{tabular}{ccc}
\hline & & Stress study final conditions \\
\hline S. No & Degradation type & Experimental Condition \\
\hline 1 & Acid degradation & $2 \mathrm{~N} \mathrm{HCl}, 80^{\circ} \mathrm{C}$ Reflux $8 \mathrm{~h}$ \\
2 & Base degradation & $2 \mathrm{~N} \mathrm{NaOH}, 80^{\circ} \mathrm{C}$ Reflux $8 \mathrm{~h}$ \\
3 & Oxidative degradation & $30 \% \mathrm{H}_{2} \mathrm{O}_{2}, 80^{\circ} \mathrm{C}$ Reflux $8 \mathrm{~h}$ \\
4 & Thermal degradation & $110^{\circ} \mathrm{C}, 24 \mathrm{~h}$ \\
5 & Photolytic degradation & Solid sample exposed to $254 \mathrm{~nm}$ in UV Chamber 2 days \\
\hline
\end{tabular}


$3 \mathrm{~mL}$ of mobile phase. For acidic degradation, $200 \mathrm{mg}$ of Nevirapine was dissolved in 5 $\mathrm{mL}$ of $2 \mathrm{~N} \mathrm{HCl}$ solution $\left(80^{\circ} \mathrm{C}\right.$, Reflux) and degraded sample was neutralized with $2 \mathrm{~N}$ ammonium bicarobonate solution. Resultant solution was lyophilized to get free solid and same sample was dissolved in $3 \mathrm{~mL}$ of mobile phase.

\section{Results and Discussion}

\subsection{Method Development of Chromatographic Conditions for Analysis of Nevirapine and Isolation of Degradation Products}

The main object of this work was to develop new stability indicating analytical method for analysis of Nevirapine and isolation, characterization of unknown degradation product. Forced degradation studies were carried out to identify the degradation products and prove the stability indicating nature of reverse chromatographic method. To achieve the objectives of the method, development was carried out as follows.

To get separation of Nevirapine from its degradation products different chromatographic methods were tried using different stationary phases like C18, C8. Initial experiment was started with waters Symmetry C18 $(75 \times 4.63 .5 \mu)$ column, but Nevirapine related compound-A was not separating from drug peak and shape of the peak also not good. System suitability parameters were not passed with using waters Acquity BEH C18 $(50 \times 2.11 .7 \mu)$ column. Further method development was carried using waters X-Bridge column, Acquity BEH C8 and Agilent Eclipse C18 column. From the all trials it has been observed that Eclipse plus C18 $(50 \times 4.61 .8 \mu)$ seems to be better eluting all peaks with good separation and peak shape.

For purification of degradation products different preparative columns were tried like X-Select CSH C18 $(150 \times 195 \mu)$, X-Bridge C18 $(150 \times 195 \mu)$, YMC Trait C18 $(150 \times 2010 \mu$ Packed), X-Select Cyano $(250 \times 195 \mu)$. Acid degradation product was dragging the column upto 4 to 5 minutes in initial tried columns but in waters cyano column (X-Select Cyano $(250 \times 195 \mu))$ only giving good peak shape. From the all early experiments based on different chromatographic systems, finally X-Select Cyano (250 $\times$ $195 \mu$ ) column was selected for good loadability, peak shape and separation.

To select the organic solvent for method development methanol and acetonitrile were tried. Compare to methanol, acetonitrile was showing good separations and less column back pressure. Hence acetonitrile was selected as organic modifier for the method development. As we need to purify the degradation products volatile aqueous mobile phases tried like ammonium acetate, ammonium bicarbonate, formic acid, trifluroacetic acid. $10 \mathrm{mM}$ Ammonium bicarbonate was selected as aqueous buffer for good peak shape and system suitable results. Combination of Acetonitrile and $10 \mathrm{mM} \mathrm{Am-}$ monium bicarbonate achieved good separation, peak shape and good recovery of degradation products. Standard chromatogram of Nevirapine was shown in Figure 2.

\subsection{Identification of Degradation Products of Nevirapine}

Degradation was not found in base hydrolysis, Oxidative degradation and photolytic conditions which confirms that Nevirapine was found to be stable to base, oxidative 
degradation and photolytic conditions. The drug was found to be liable to acid hydrolysis as a total of $20.91 \%$ degradation was found $\left(2 \mathrm{~N} \mathrm{HCl}\right.$ at $80^{\circ} \mathrm{C}$, up to $8 \mathrm{~h}$ ) with a maximum individual degradation product of $14.48 \%$. The drug degradation was also found in thermal degradation of $16.48 \%$ (at $110^{\circ} \mathrm{C}$, up $24 \mathrm{~h}$ ) with a maximum individual degradation product of $9.98 \%$. The method was specific because degradation products were separated to base line from main component and the peak purity flag passes for drug and degradation products which confirms the method is selective and homogeneity of the drug product. Degradation results of Nevirapine were shown in Table 4. Thermal and acid degradation chromatograms were shown in Figure 3 and Figure 4.

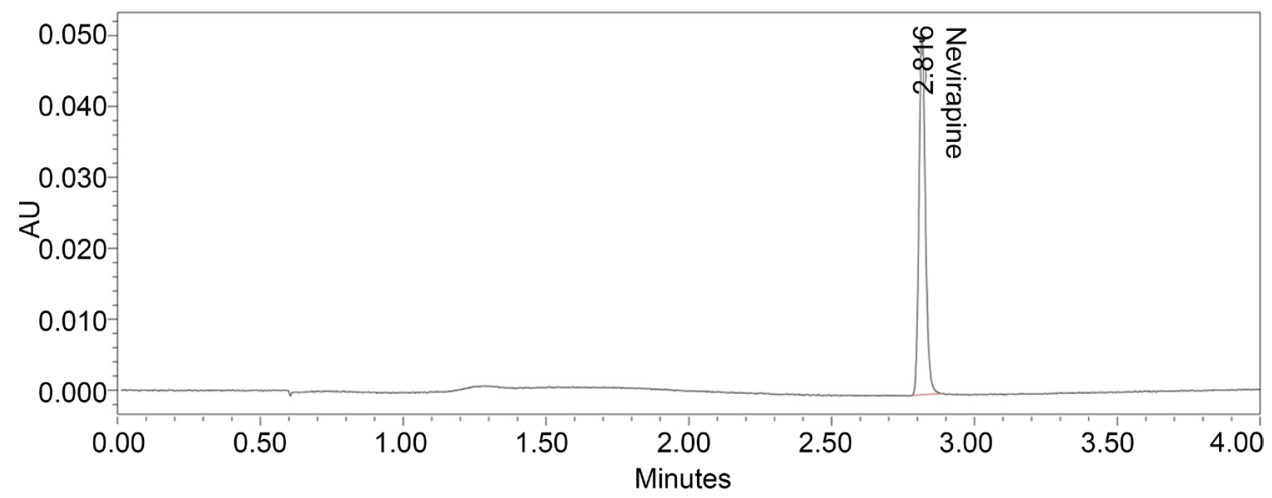

Figure 2. Standard chromatogram of Nevirapine.

Table 4. Degradation results of Nevirapine.

\begin{tabular}{|c|c|c|c|}
\hline $\begin{array}{c}\text { Type of } \\
\text { degradation }\end{array}$ & $\begin{array}{c}\% \text { of Drug compound } \\
\text { and Peak purity }\end{array}$ & $\begin{array}{l}\% \text { of Degradation product } \\
\text { (1) and Peak purity }\end{array}$ & $\begin{array}{c}\% \text { of Degradation product } \\
\text { (2) and Peak purity }\end{array}$ \\
\hline $\begin{array}{c}\text { Acid } \\
\text { degradation }\end{array}$ & 79.09 (Passed) & 6.43 (Passed) & 14.48 (Passed) \\
\hline $\begin{array}{c}\text { Base } \\
\text { degradation }\end{array}$ & $\begin{array}{c}\text { No degradation } \\
\text { observed }\end{array}$ & - & - \\
\hline $\begin{array}{c}\text { Thermal } \\
\text { Degradation }\end{array}$ & 83.52 (Passed) & 6.50 (Passed) & 9.98 (Passed) \\
\hline $\begin{array}{c}\text { Oxidative } \\
\text { degradation }\end{array}$ & $\begin{array}{c}\text { No degradation } \\
\text { observed }\end{array}$ & - & - \\
\hline $\begin{array}{l}\text { Photolytic } \\
\text { degradation }\end{array}$ & $\begin{array}{c}\text { No degradation } \\
\text { observed }\end{array}$ & - & - \\
\hline
\end{tabular}

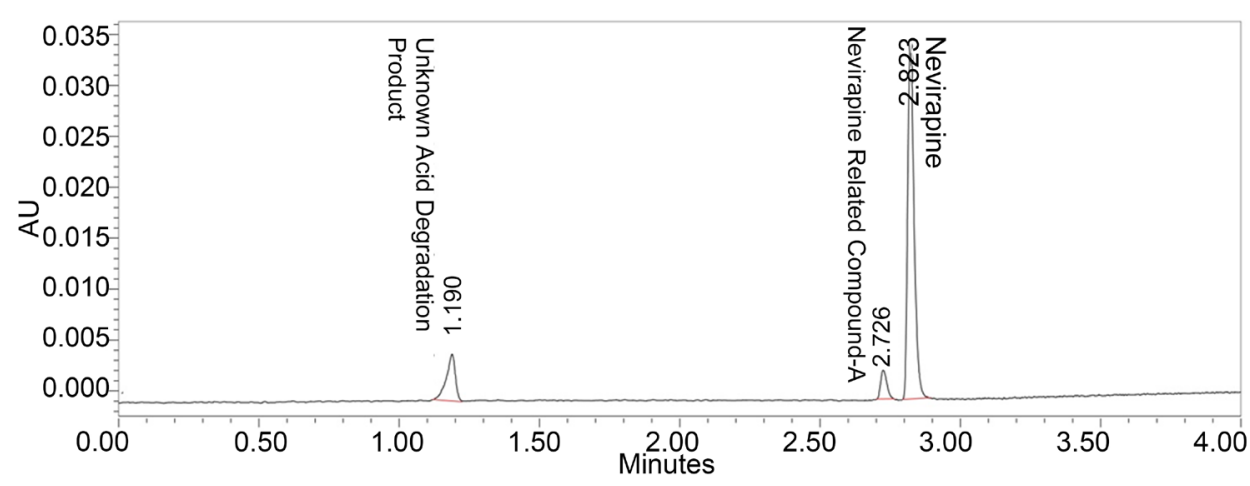

Figure 3. Acid degradation chromatogram of Nevirapine. 


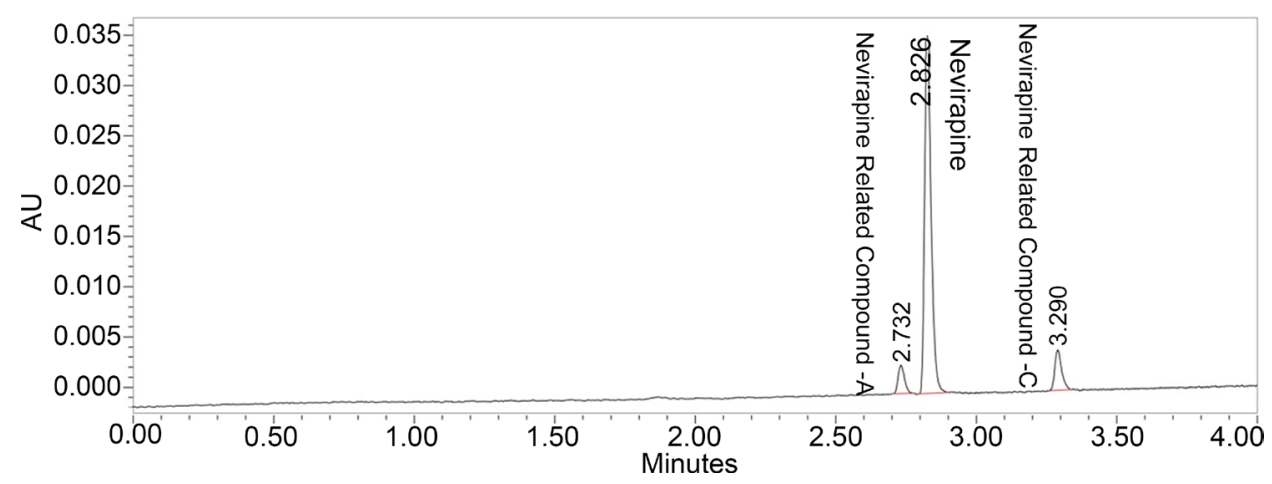

Figure 4. Thermal degradation chromatogram of Nevirapine.

\subsection{Isolation of Degradation Products of Nevirapine}

As degradation was observed in acid and thermal stress condition, we intended to isolate degradation products of Nevirapine. For purification of degradation products several chromatographic conditions were tried to get good peak shape, recovery and loadabuility. Finally desired separation was achieved using the $10 \mathrm{mM}$ ammonium bicarbonate and acetonitrile as a mobile phase and X-Select HSS CN OBD ${ }^{\mathrm{TM}}(250 \times 195 \mu)$ column. Thermal degradation and acid degradation crude sample solutions were injected in consecutive injections. The fractions have been collected on the basis of mass threshold parameters of total ion chromatogram. After completion of thermal degradation crude sample purification collected all fractions of mass $227.09(\mathrm{M}+\mathrm{H})$, mass $269.1(\mathrm{M}+\mathrm{H})$, pooled together and lyophilized to get free solids. In acid degradation fractions of mass $227.09(\mathrm{M}+\mathrm{H})$, mass $245.1(\mathrm{M}+\mathrm{H})$, pooled together and lyophilized to get free solids.

\subsection{Structure Confirmation of Degradation Products}

To get structural insight, the HRMS analysis was carried out on isolated degradation samples. Thermal degradation products mass spectrums thus obtained were shown the protonated molecular ion $\mathrm{m} / \mathrm{z} 227.0938, \mathrm{~m} / \mathrm{z} 269.1407$ respectively. These two masses confirms that thermal degradation products were Nevirapine related compounds A and C. Nevirapine related compounds $A$ and $C$ further confirmed with ${ }^{1} \mathrm{H}$ NMR which was compiled with structures. Acid degradation products were shown the protonated molecular ion m/z 227.0938, m/z 245.1033 respectively. From the HRMS data m/z 227.0938 indicates formed degradation product was Nevirapine related compound $\mathrm{A}$ and which was confirmed with ${ }^{1} \mathrm{H}$ NMR. The protonated mass m/z 245.1033 was found as unknown degradation product and further characterized by ${ }^{1} \mathrm{H}$ NMR, $\mathrm{D}_{2} \mathrm{O}$ Exchange, ${ }^{13} \mathrm{C}$ NMR, HMBC, HSQC and FT-IR.

\subsection{Structure Elucidation of Unknown Acid Degradation Product}

The HRMS data of this degradation product showed exact mass of the protonated molecular ion at m/z 245.1033 (Calculated 244.10) which corresponds to the protonated molecular formula $\mathrm{C}_{12} \mathrm{H}_{13} \mathrm{~N}_{2} \mathrm{O}_{4}$. The ${ }^{1} \mathrm{H}$ NMR, ${ }^{13} \mathrm{C}$ NMR and ${ }^{2} \mathrm{D}$ NMR spectral data of 
degradation product was compared with those of Nevirapine and the numbering scheme for the NMR assignments is shown in Figure 5. In ${ }^{1} \mathrm{H}$ NMR, presence of cyclopropyl ring protons in Nevirapine, were missing in degradation product as well in ${ }^{13} \mathrm{C}$ NMR, presence of cyclopropyl group carbons in Nevirapine were missing in degradation product. In ${ }^{1} \mathrm{H}$ NMR nitrogen attached two protons (singlet) are not seen in Nevirapine and which were exchanged in $\mathrm{D}_{2} \mathrm{O}$. In Nevirapine only one exchangeable proton was present, where as degradation compound has 3 exchangeable protons $(2 \mathrm{H}, \mathrm{s}, 1 \mathrm{H}$, s). ${ }^{13} \mathrm{C}-{ }^{1} \mathrm{H}$ connectivity in the degradation product was confirmed by HSQC and HMBC NMR spectral data. Thus the degradation impurity structure can be rationalized in terms of formation of assuming structure.

IR absorption spectral data of degradation product also supporting that formation of one carboxylic acid $(-\mathrm{COOH})$ functional group and primary amine $\left(-\mathrm{NH}_{2}\right)$ functional group. Presence of IR absorption bands for this compound $\left(\mathrm{cm}^{-1}\right)$ are 2853.81, 2924.21, $3006.193331 .21,3423.80,3483.59,1665.60$ clearly indicates presence of carboxylic acid and amine functional groups.

From all the spectral data, the structure of the degradation product was characterized as 2-(3-Amino-4-methylpyridin-2-ylamino) nicotinic acid with molecular formula $\mathrm{C}_{12} \mathrm{H}_{12} \mathrm{~N}_{2} \mathrm{O}_{4}$ and molecular weight 244.10. All chemical shift values, HSQC and HMBC correlations were shown in Table 5. HRMS Report and complete spectral data were shown in Figures 6-9. Proposed mechanism for formation of acid degradation product was shown in Figure 10.

\subsection{Method Validation}

The developed UPLC method was taken up for validation. The analytical method validation [18] was carried in accordance with ICH guidelines.

\subsubsection{Assay}

Prepared standard and sample solutions were injected into developed chromatographic conditions and $\%$ of assay was calculated and the $\%$ of assay was found to be $99.6 \%$.

\subsubsection{System Suitability Test}

Standard solution of Nevirapine $\left(15 \mu \mathrm{g} \cdot \mathrm{mL}^{-1}\right)$ injected into the developed UPLC method to know the system suitability results. The typical retention time of Nevirapine is $2.82 \mathrm{~min}$, USP tailing 1.21 and USP Plate count is 85350.

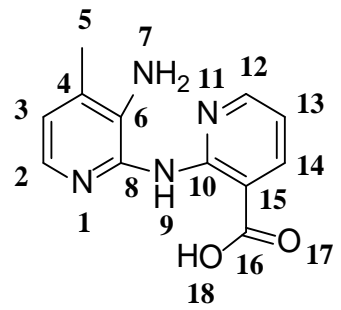

Figure 5. Assumed structure of unknown acid degradation product and its numbering scheme. 
Table 5. Chemical shift values and correlations of unknown acid degradation product.

\begin{tabular}{|c|c|c|c|c|c|}
\hline S.No & Label & $\begin{array}{c}{ }^{1} \mathrm{H} \text { Chemical Shift } \\
\text { (in PPM) }\end{array}$ & $\begin{array}{c}{ }^{13} \mathrm{C} \text { Chemical Shift } \\
\text { (in PPM) }\end{array}$ & $\begin{array}{c}\text { HSQC } \\
\text { (Hetero nuclear single } \\
\text { quantum correlations) }\end{array}$ & $\begin{array}{c}\text { HMBC } \\
\text { (Hetero nuclear multiple bond } \\
\text { correlations) }\end{array}$ \\
\hline 1 & 1 & - & - & - & - \\
\hline 2 & 2 & $7.722(d)$ & 144.186 & $7.722\left({ }^{1} \mathrm{H}\right), 144.186\left({ }^{13} \mathrm{C}\right)$ & $114.657,143.873,157.550$ \\
\hline 3 & 3 & $6.497(d)$ & 114.657 & $6.497\left({ }^{1} \mathrm{H}\right), 114.657\left({ }^{13} \mathrm{C}\right)$ & $17.683,119.682,143.873$ \\
\hline 5 & 5 & $2.011(3 \mathrm{H}, \mathrm{s})$ & 17.683 & $2.011\left({ }^{1} \mathrm{H}\right), 17.683\left({ }^{13} \mathrm{C}\right)$ & $114.657,119.682,143.873$ \\
\hline 6 & 6 & - & 119.682 & $119.682\left({ }^{13} \mathrm{C}, \mathrm{q}\right)$ & - \\
\hline 7 & 7 & $5.639(2 \mathrm{H}, \mathrm{s})$ & - & - & - \\
\hline 8 & 8 & - & 157.550 & $157.550\left({ }^{13} \mathrm{C}, \mathrm{q}\right)$ & - \\
\hline 12 & 12 & $8.143(d)$ & 150.662 & $8.143\left({ }^{1} \mathrm{H}\right), 150.662\left({ }^{13} \mathrm{C}\right)$ & $139.673,156.885,112.512$ \\
\hline 13 & 13 & $6.679(t)$ & 112.512 & $6.679\left({ }^{1} \mathrm{H}\right), 112.512\left({ }^{13} \mathrm{C}\right)$ & $112.112,150.662$ \\
\hline 14 & 14 & $8.069(\mathrm{~d})$ & 139.673 & $8.069\left({ }^{1} \mathrm{H}\right), 139.673\left({ }^{13} \mathrm{C}\right)$ & $150.662,156.885,169.858$ \\
\hline 15 & 15 & - & 112.112 & $112.112\left({ }^{13} \mathrm{C}, \mathrm{q}\right)$ & - \\
\hline 16 & 16 & - & 169.858 & $169.858\left({ }^{13} \mathrm{C}, \mathrm{q}\right)$ & - \\
\hline 17 & 17 & - & - & - & - \\
\hline 18 & 18 & $\sim 11$ (not detected due to moisture) & - & - & - \\
\hline
\end{tabular}

Elemental Composition Report

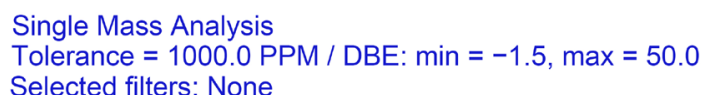

Monoisotopic Mass, Even Electron lons

13 formula(e) evaluated with 1 results within limits (up to 1 closest results for each mass) Elements Used:

$\begin{array}{llll}\mathrm{C}: 0-12 & \mathrm{H}: 0-13 & \mathrm{~N}: 0-4 & 0: 0-2\end{array}$ NVP-244

05-01-2016-021-NVP-244 27 (0.382) AM (Top,4, Ar,5000.0,195.16,1.00,LS 10);Sm (Mn, 2×1.00); Sb $(1,40.00)$

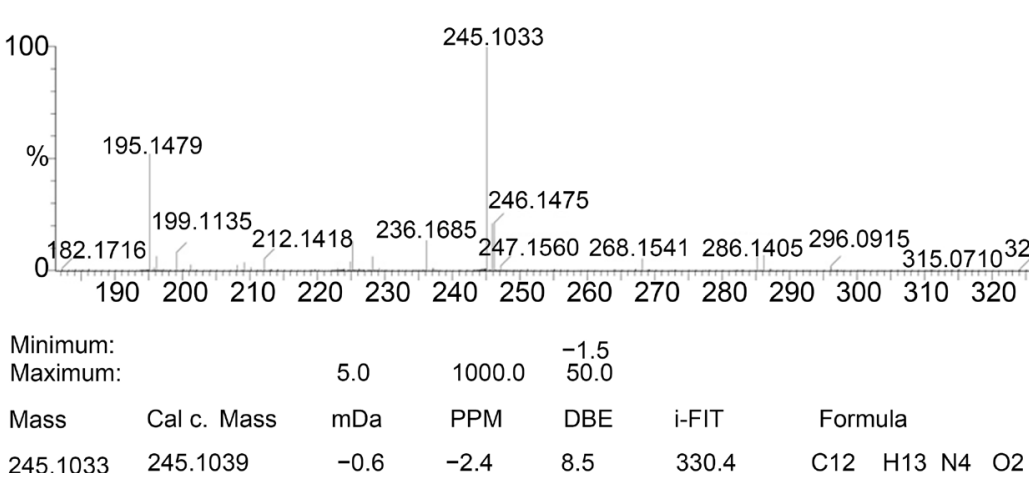

Figure 6. HRMS report of unknown acid degradation product of Nevirapine. 


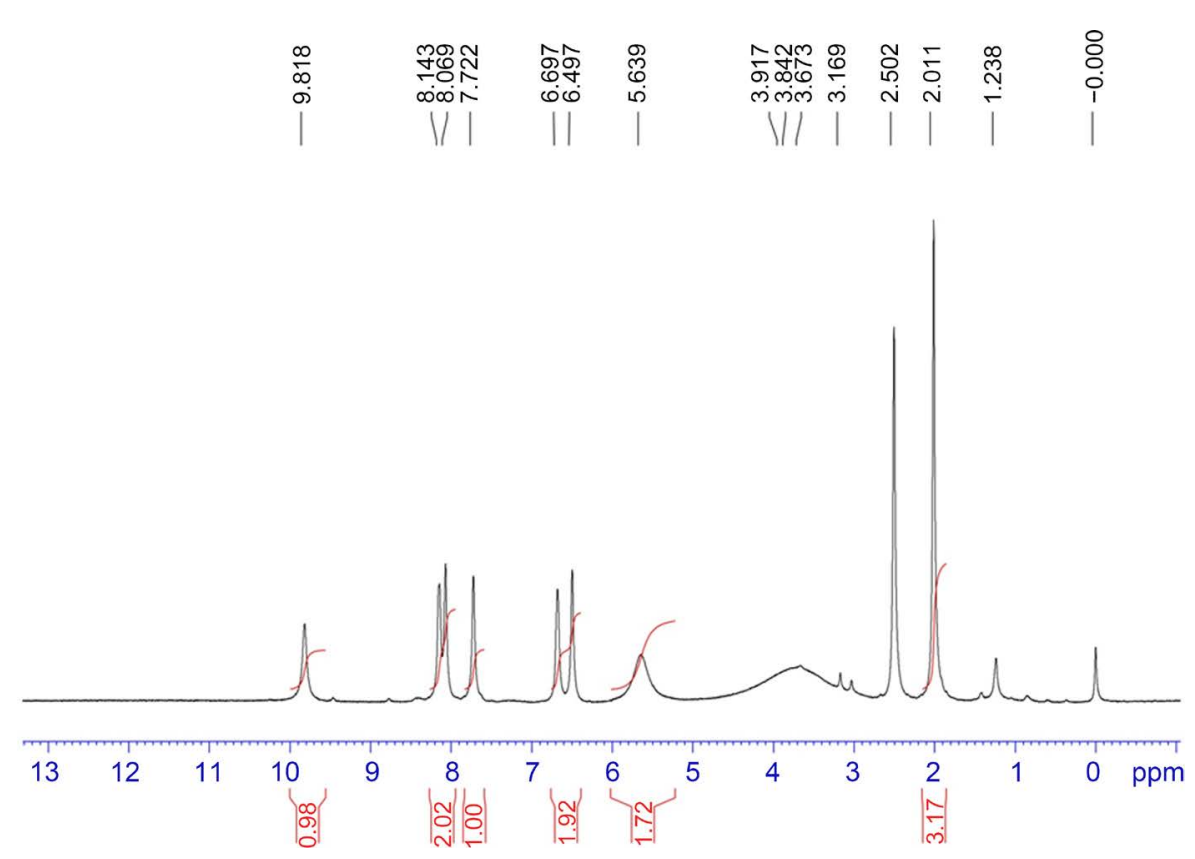

Figure 7. ${ }^{1} \mathrm{H}$ NMR spectrum of unknown acid degradation product of Nevirapine.

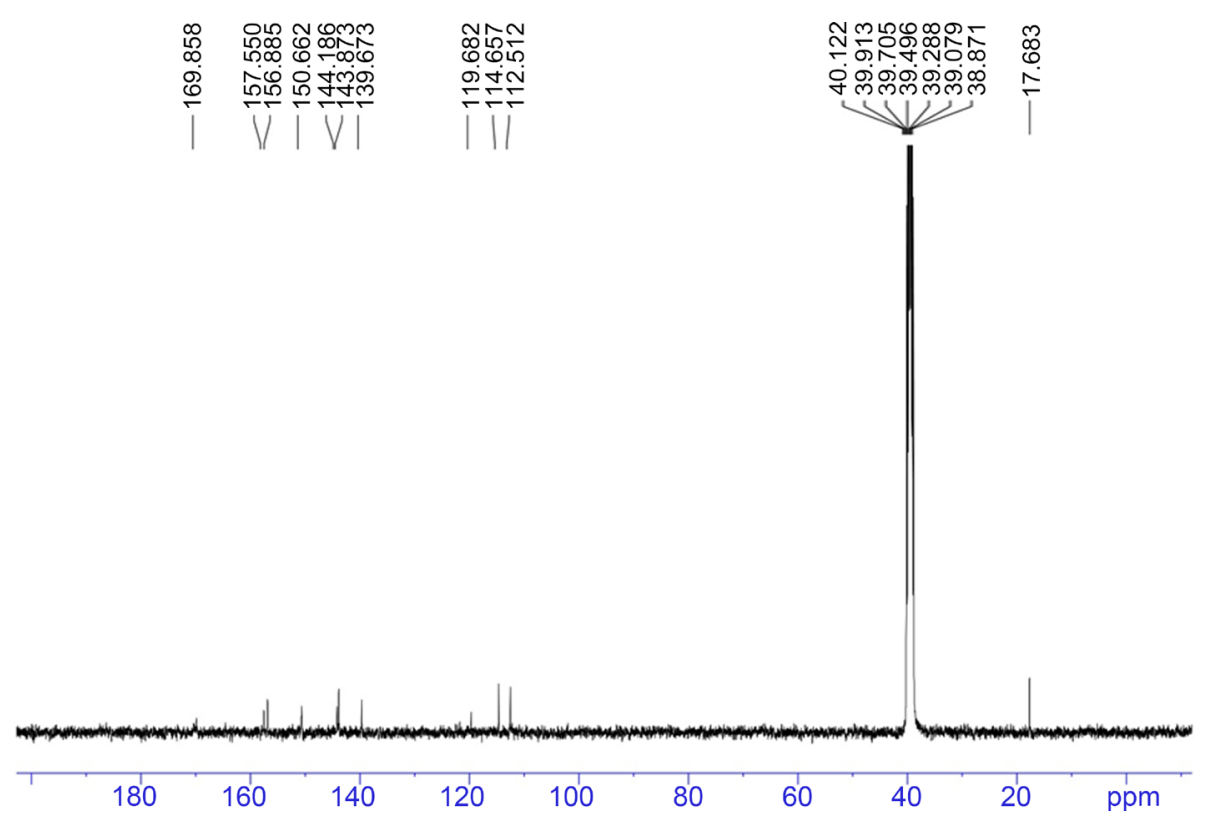

Figure $8 .{ }^{13} \mathrm{C}$ spectrum of acid degradation product.

\subsubsection{Precision}

The repeatability was checked by repeatedly injecting $(n=6)$ standard solution of $\mathrm{Ne}$ virapine. Retention times and the area RSD values for Nevirapine were found to be within $2.0 \%$ confirming a suitable precision of the method. Precision results were shown in Table 6.

\subsubsection{Linearity}

The linear regression equation is $y=5581 x-300$ and the correlation coefficient 


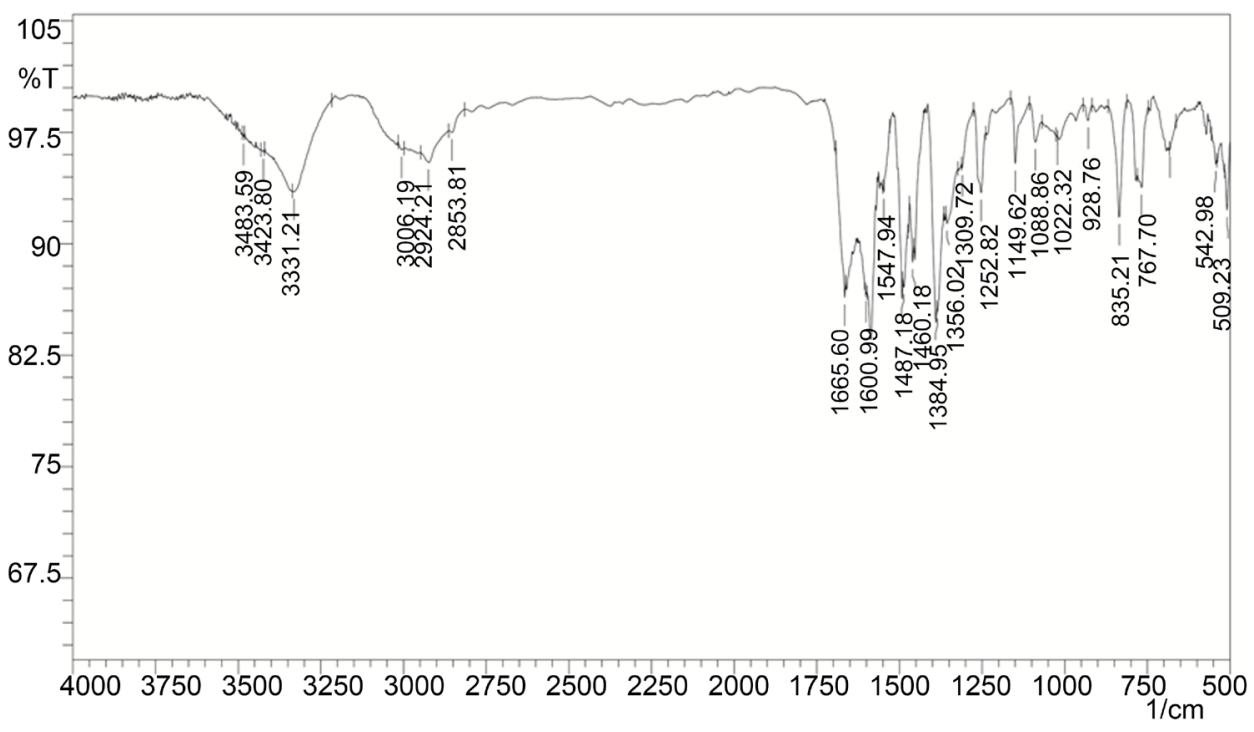

Figure 9. FT-IR spectrum of unknown acid degradation product of Nevirapine.

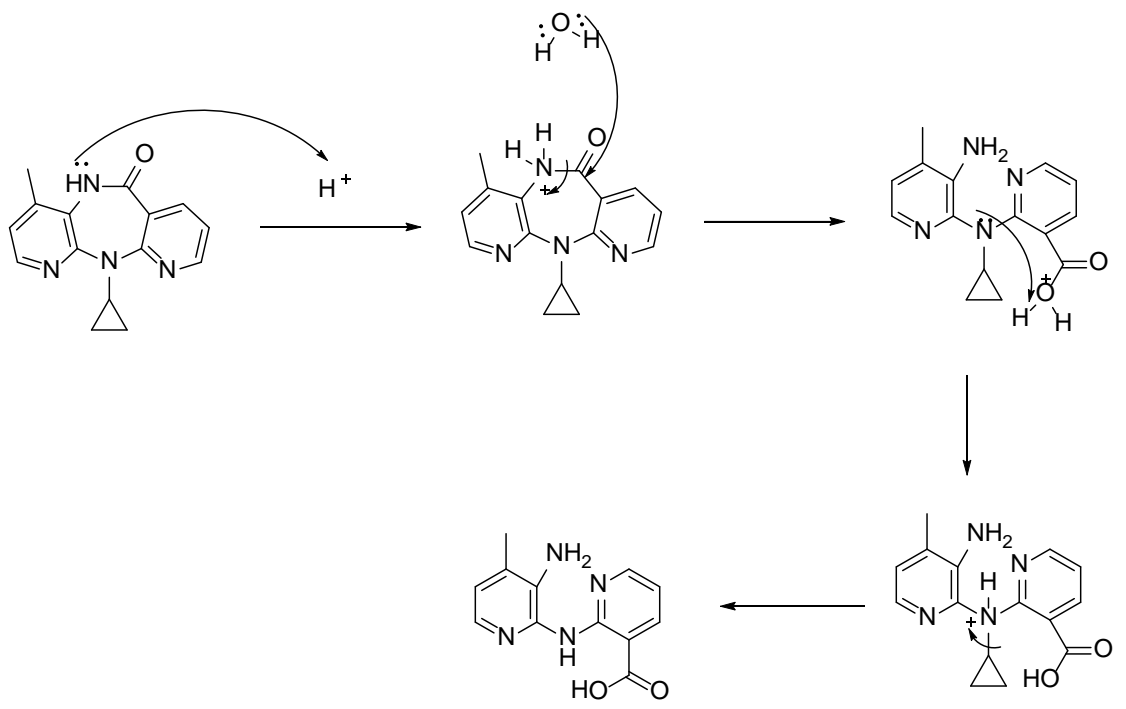

Figure 10. Proposed mechanism for formation of acid degradation product.

Table 6. Precision results of Nevirapine.

\begin{tabular}{|c|c|c|c|c|c|}
\hline \multicolumn{3}{|c|}{ Inter day Precision } & \multicolumn{3}{|c|}{ Intraday Precision } \\
\hline S. No & Area & Assay & S. No & Area & Assay \\
\hline 1 & 38,985 & 98.94 & 1 & 39,877 & 101.21 \\
\hline 3 & 38,978 & 98.93 & 3 & 39,756 & 100.90 \\
\hline 4 & 39,154 & 99.37 & 4 & 38,564 & 97.88 \\
\hline 5 & 38,995 & 98.97 & 5 & 39,147 & 99.35 \\
\hline Average & $39,053.33$ & 99.11667 & Average & $39,147.33$ & 99.35667 \\
\hline Standard Deviation & 106.2011 & 0.267856 & Standard Deviation & 552.8069 & 1.401994 \\
\hline Relative Standard Deviation & 0.27 & 0.27 & Relative Standard Deviation & 0.14 & 0.14 \\
\hline
\end{tabular}


obtained was greater than 0.99 for tablet dosage form which confirmed the linear relationship between peak areas and concentrations. Slope and $Y$-Intercept values were 5581 and -300 . Linearity was determined for six concentrations of each three replicate injections. The linearity test results were shown in Table 7 . Linearity curve was shown in Figure 11.

\subsubsection{Accuracy}

Assay method was conducted to determine accuracy of the method. The study was carried out at $50 \%, 100 \%$ and $150 \%$ for three replicate injections of each concentration of the analyte followed by calculation of the assay and results were shown in Table 8.

\subsubsection{Limit of Quantification (LOQ) and Limit of Detection}

In accordance with International Conference on Harmonization (ICH) recommendations, the approach based on the standard deviations (SD) of the response and the slope of the calibration plot was used for determinations of limit of detection and limit of quantification. LOD and LOQ of drug calculated using the following equations designated by International Conference on Harmonization ( $\mathrm{ICH}$ ) guidelines.

$$
\begin{aligned}
& \mathrm{LOD}=3.3 \times \sigma / \mathrm{S} \\
& \mathrm{LOQ}=10 \times \sigma / \mathrm{S}
\end{aligned}
$$

where, $\sigma=$ the standard deviation of the response.

$\mathrm{S}=$ slope of the calibration curve.

The limit of detection (LOD) and limit of quantification (LOQ) for Nevirapine were found to be $0.898 \mu \mathrm{g} \cdot \mathrm{mL}^{-1}$ and $2.723 \mu \mathrm{g} \cdot \mathrm{ml}^{-1}$ respectively. These data shows that method is sensitive for the determination of Nevirapine.

\subsubsection{Solution Stability, Mobile Phase Stability, Robustness and Ruggedness}

The stability of Nevirapine was assessed during storage and analysis. No significant changes were observed in the content of Nevirapine in mobile phase stability experiments. The standard, sample solutions prepared in clear volumetric flasks were stable up to 40 days in temperature from $2^{\circ} \mathrm{C}$ to $8^{\circ} \mathrm{C}$. Robustness as a measure of method capability to remain unaffected by minute, but intentional changes in chromatographic conditions was studied by testing influence of small changes in mobile phase $p \mathrm{H}( \pm$ 0.2 ), organic phase composition (90\% to $110 \%)$, column temperature $\left( \pm 5^{\circ} \mathrm{C}\right)$ and flow rate $\left( \pm 0.2 \mathrm{~mL} \cdot \mathrm{min}^{-1}\right)$. The effect of different column, different analyst, and different system was also studied as part of the ruggedness of the method. System suitability

Table 7. Results of concentration vs area of Nevirapine.

\begin{tabular}{cc}
\hline Concentration $\left(\right.$ in $\left.\mu \mathrm{g} \cdot \mathrm{mL}^{-1}\right)$ & Average area of five injections \\
\hline 5 & 27,606 \\
10 & 55,212 \\
15 & 82,818 \\
20 & 113,424 \\
25 & 138,030 \\
\hline
\end{tabular}




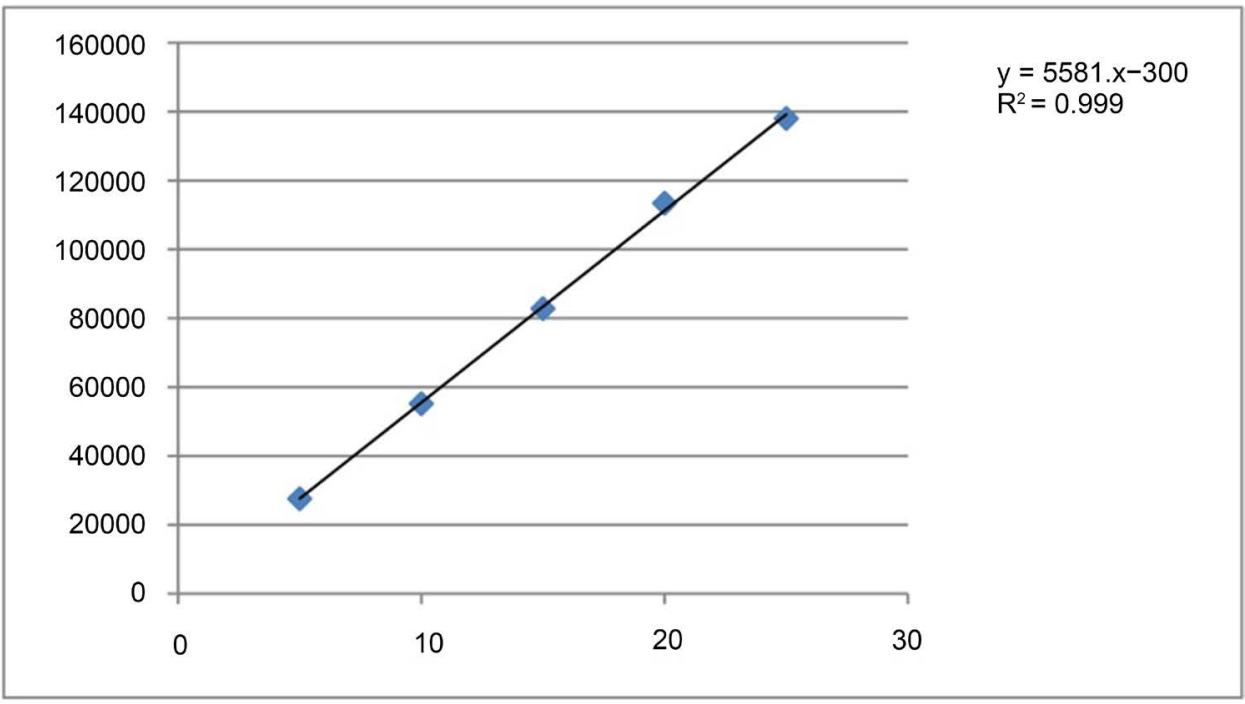

Figure 11. Linearity curve of Nevirapine.

Table 8. Accuracy results of Nevirapine.

\begin{tabular}{ccccc}
\hline S. No & Concentration & Area & Assay $(\%)(\mathrm{n}=3)$ & \% RSD \\
\hline 1 & 50 & 19598 & 99.48 & $<0.1$ \\
2 & 100 & 39335 & 99.83 & $<0.1$ \\
3 & 150 & 58933 & 99.71 & $<0.1$ \\
\hline
\end{tabular}

parameters like USP plate count, USP tailing were checked and they found to be within the limits.

\subsubsection{Specificity}

Forced degradation study of the drug substance can help to identify the stability of the molecule and possible degradation products and also validate the stability and specificity of the analytical procedures. Acid, base, thermal, oxidative and photolytic degradation sample solutions were injected into the developed method to know the specificity of the method. Degradation was observed in acidic, thermal conditions. Developed method was able to separate all degradation products from drug compound, so it can be employed as stability indicating method. Degradation was not observed in base, oxidative and photolytic conditions. Degradation results were shown in Table 9.

\section{Conclusion}

The simple, fast and economic method was developed to analysis of Nevirapine. Forced degradation studies were performed to assess the stability of the compound and prove the stability indicating nature of the developed chromatographic method. All degradation products were isolated and two of them confirmed as reported impurities. In acid degradation study unknown impurity was observed and that impurity was isolated and confirmed the structure by using spectroscopic techniques like NMR, Mass and FT-IR. 
Table 9. Degradation and system suitability results of Nevirapine.

\begin{tabular}{cccccc}
\hline \multicolumn{7}{c}{ Acid Degradation } & & & \\
\hline $\begin{array}{c}\text { Peak } \\
\text { Label }\end{array}$ & $\begin{array}{c}\text { Retention } \\
\text { time }\end{array}$ & \% of Area & $\begin{array}{c}\text { USP } \\
\text { Resolution }\end{array}$ & $\begin{array}{c}\text { USP } \\
\text { Tailing }\end{array}$ & $\begin{array}{c}\text { Peak } \\
\text { Purity }\end{array}$ \\
\hline Un Known Acid Degradation product & 1.190 & 14.48 & - & 0.76 & Passed \\
Nevirapine Related Compound-A & 2.726 & 6.43 & 29.59 & 1.37 & Passed \\
Nevirapine & 2.823 & 79.09 & 2.29 & 1.40 & Passed \\
\hline Nevirapine Related Compound-A & 2.732 & 6.50 & - & 1.20 & Passed \\
Nevirapine & Thermal Degradation & & & \\
\hline Nevirapine Related Compound-C & 3.29 & 9.98 & 10.52 & 1.29 & Passed \\
\hline
\end{tabular}

From results obtained from the spectral data unknown acid degradation product was confirmed to have a mass of 244.10 and with molecular formula of $\mathrm{C}_{12} \mathrm{H}_{12} \mathrm{~N}_{4} \mathrm{O}_{2}$. It was further confirmed that the isolated unknown acid degradation impurity from this method is different from the reported impurities of Nevirapine in the literature, having chemical name of 2-(3-Amino-4-methylpyridin-2-ylamino) nicotinic acid.

\section{References}

[1] www.drugbank.ca/drugs/DB00238

[2] D’Aquila, R.T., Hughes, M.D., Johnson, V.A., Fischl, M.A., Sommadossi, J.P., Liou, S.H., Timpone, J., Myers, M., Basgoz, N., Niu, M. and Hirsch, M.S. (1996) Nevirapine, Zidovudine, and Didanosine Compared with Zidovudine and Didanosine in Patients with HIV-1 Infection. A Randomized, Double-Blind, Placebo-Controlled Trial. Annals of Internal Medicine, 124, 1019-1030. http://dx.doi.org/10.7326/0003-4819-124-12-199606150-00001

[3] Montaner, J.S., Reiss, P., Cooper, D., Vella, S., Harris, M., Conway, B., Wainberg, M.A., Smith, D., Robinson, P., Hall, D. and Myers, M. (1998) A Randomized, Double-Blind Trial Comparing Combinations of Nevirapine, Didanosine, and Zidovudine for HIV-Infected Patients: The INCAS Trial. JAMA, 279, 930-937. http://dx.doi.org/10.1001/jama.279.12.930

[4] Floridia, M., Bucciardini, R., Ricciardulli, D., Fragola, V., Pirillo, M.F., Weimer, L.E., Tomino, C., Giannini, G., Galluzzo, C.M., Andreotti, M. and Cargnel, A. (1999) A Randomized, Double-Blind Trial on the Use of a Triple Combination Including Nevirapine, a Nonnucleoside Reverse Transcriptase HIV Inhibitor, in Antiretroviral-Naive Patients with Advanced Disease. JAIDS Journal of Acquired Immune Deficiency Syndromes, 20, 11-19. http://dx.doi.org/10.1097/00042560-199901010-00002

[5] Asmuth, D. and Pollard, R. (2006) Nevirapine. In: Reverse Transcriptase Inhibitors in HIVIAIDS Therapy, Humana Press, 303-344.

http://dx.doi.org/10.1007/978-1-59745-085-0_11

[6] Podzamczer, D., Ferrer, E., Consiglio, E., Gatell, J.M., Perez, P., Perez, J.L., Luna, E., González, A., Pedrol, E., Lozano, L. and Ocaña, I. (2002) A Randomized Clinical Trial Comparing Nelfinavir or Nevirapine Associated to Zidovudine/Lamivudine in HIVInfected Naive Patients (the Combine Study). Antiviral Therapy, 7, 81-90.

[7] Ferrer, E., Santamariña, E., Domingo, P., Fumero, E., Ribera, E., Knobel, H., Lopez, J.C., 
Barrios, A. and Podzamczer, D. (2004) Nevirapine-Containing Regimens in HIV-Infected Naive Patients with CD4 Cell Counts of 200 Cells/ $\mu$ or Less. Aids, 18, 1727-1729. http://dx.doi.org/10.1097/01.aids.0000131381.07609.19

[8] De Clercq, E. (1999) Perspectives of Non-Nucleoside Reverse Transcriptase Inhibitors (NNRTIs) in the Therapy of HIV-1 infection. Il Farmaco, 54, 26-45.

http://dx.doi.org/10.1016/S0014-827X(98)00103-7

[9] Droste, J.A.H., Verweij-van Wissen, C.P.W.G.M. and Burger, D.M. (2003) Simultaneous Determination of the HIV Drugs Indinavir, Amprenavir, Saquinavir, Ritonavir, Lopinavir, Nelfinavir, the Nelfinavir Hydroxymetabolite M8, and Nevirapine in Human Plasma by Reversed-Phase High-Performance Liquid Chromatography. Therapeutic Drug Monitoring, 25, 393-399. http://dx.doi.org/10.1097/00007691-200306000-00023

[10] Kappelhoff, B.S., Rosing, H., Huitema, A.D. and Beijnen, J.H. (2003) Simple and Rapid Method for the Simultaneous Determination of the Non-Nucleoside Reverse Transcriptase Inhibitors Efavirenz and Nevirapine in Human Plasma Using Liquid Chromatography. Journal of Chromatography B, 792, 353-362. http://dx.doi.org/10.1016/S1570-0232(03)00325-8

[11] Lopez, R.M., Pou, L., Gomez, M.R., Ruiz, I. and Monterde, J. (2001) Simple and Rapid Determination of Nevirapine in Human Serum by Reversed-Phase High-Performance Liquid Chromatography. Journal of Chromatography B: Biomedical Sciences and Applications, 751, 371-376. http://dx.doi.org/10.1016/S0378-4347(00)00476-X

[12] Van Heeswijk, R.P., Hoetelmans, R.M., Meenhorst, P.L., Mulder, J.W. and Beijnen, J.H., (1998) Rapid Determination of Nevirapine in Human Plasma by Ion-Pair Reversed-Phase High-Performance Liquid Chromatography with Ultraviolet Detection. Journal of Chromatography B: Biomedical Sciences and Applications, 713, 395-399. http://dx.doi.org/10.1016/S0378-4347(98)00217-5

[13] Ravisankar, P. and Devala Rao, G. (2013) Development of a New RP-HPLC method for the Estimation of Nevirapine in Tablet Dosage Form. International Journal of Pharmacy and Pharmaseutical Sciences, 5, 505-511.

[14] Marinho, A.T., Godinho, A.L., Novais, D.A., Antunes, A.M., Marques, M.M., Ramos, T., Dias, C.G., Monteiro, E.C. and Pereira, S.A. (2014) Development and Validation of an HPLC-UV Method for Quantifying Nevirapine and Its Main Phase I Metabolites in Human Blood. Analytical Methods, 6, 1575-1580. http://dx.doi.org/10.1039/c3ay41911h

[15] Valluru, R.K., Kumar, P. and Kilaru, N.B. (2013) High Throughput LC-MS/MS Method for Simultaneous Determination of Tenofovir, Lamivudine and Nevirapine in Human Plasma. Journal of Chromatography B, 931, 117-126. http://dx.doi.org/10.1016/j.jchromb.2013.05.008

[16] ICH (2003) Stability Testing of New Drug Substances and Products Q1A (R2), International Conference on Harmonization, IFMPA, Geneva.

[17] TPD (1997) Stability Testing of Existing Drug Substances and Products Directorate Ottawa.

[18] International Conferences on Harmonization (2005) Q2 (R1); Validation of Analytical Procedures: Text and Methodology. 
Submit or recommend next manuscript to SCIRP and we will provide best service for you:

Accepting pre-submission inquiries through Email, Facebook, LinkedIn, Twitter, etc. A wide selection of journals (inclusive of 9 subjects, more than 200 journals)

Providing 24-hour high-quality service

User-friendly online submission system

Fair and swift peer-review system

Efficient typesetting and proofreading procedure

Display of the result of downloads and visits, as well as the number of cited articles

Maximum dissemination of your research work

Submit your manuscript at: http://papersubmission.scirp.org/

Or contact ajac@scirp.org 